\title{
TrANSLATING HOMER / TRADUZINDO HOMERO
}

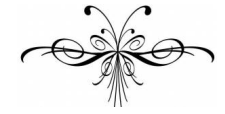 \\ SAMUEL JOHNSON \\ Gustavo Althoff, Mauri Furlan (TRADUtOREs)
}

amuel Johnson (1709-1784), crítico, ensaísta, jornalista, poeta,
educador e lexicógrafo, é considerado uma das personalidades mais
proeminentes no mundo intelectual da Bretanha do século XVIII. Em 1777, ele recebeu a proposta de um grupo de livreiros para escrever uma série de vidas de poetas ingleses, e entre 1779-81 foi publicada a obra The Lives of the English Poets, a qual contém a vida de Alexander Pope (1688-1744), de onde extraímos o excerto abaixo. (Robinson, 2002) ${ }^{1}$

Samuel Johnson elogia o trabalho de Pope na tradução de Homero e a sua contribuição para a versificação em inglês. E observa que a tradução de Pope não é fiel e não tem a simplicidade do original. Johnson, contudo, justifica as variações apresentadas por Pope em sua tradução em razão da distância existente entre as línguas, as épocas, os lugares. Nas palavras de Ballard (1992:210)²,

O que parece faltar à maioria dos tradutores desta época (e de outros ainda) é a perspicácia (ou a honestidade) de se situar a si mesmos numa escala que vai da reprodução cuidadosa das caracterísitcas linguístico-culturais do texto de partida à adaptação mais ou menos produzida para as exigências linguístico-culturais do público de chegada. Johnson finalmente destaca o cuidado para um escritor (denominação significativa neste caso para o tradutor) ser lido e apreciado.

\footnotetext{
${ }^{1}$ Robinson, Douglas. Western Translation Theory, from Herodotus to Nietzsche. Manchester: St. Jerome Publishing, 2002.

${ }^{2}$ BALlard, Michel. De Ciceron a Benjamin, traducteurs, traductions, réflexions. Lille: Presses Universitaires, 1992.
} 


\section{Translating Homer}

The train of my disquisition has now conducted me to that poetical wonder, the translation of the Iliad; a performance which no age or nation can pretend to equal. To the Greeks translation was almost unknown; it was totally unknown to the inhabitants of Greece. They had no recourse to the barbarians for poetical beauties, but sought for every thing in Homer, where, indeed, there is but little which they might not find.

The Italians have been very diligent translators; but I can hear of no version, unless perhaps Anguillara's Ovid may be excepted, which is read with eagerness. The Iliad of Salvini every reader may discover to be punctiliously exact; but it seems to be the work of a linguist skillfully pedantic, and his countrymen, the proper judges of its power to please, reject it with disgust.

Their predecessors the Romans have left some specimens of translation behind them, and that employment must have had some credit in which Tully and Germanicus engaged; but unless we suppose, what is perhaps true, that the plays of Terence were versions of Menander, nothing translated seems ever to have risen to high reputation. The French, in the meridian hour of their learning, were very laudably industrious to enrich their own language with the wisdom of the ancients; but found themselves reduced, by whatever necessity, to turn the Greek and Roman poetry into prose. Whoever could read an author could translate him. From such rivals little can be feared.

The chief help of Pope in this arduous undertaking was drawn from the versions of Dryden. Virgil had borrowed much of his imagery from Homer, and

\section{Traduzindo Homero}

O curso de minha disquisição ora me conduz ao prodígio poético que é a tradução da Ilíada, uma obra que nenhuma era ou nação pode pretender igualar. Para os gregos, a tradução era quase desconhecida - era totalmente desconhecida para os habitantes da Grécia. Eles não se valiam dos bárbaros para belezas poéticas, mas buscavam tudo em Homero, onde, com efeito, não há quase nada que não pudessem encontrar.

Os italianos têm sido tradutores muito diligentes; mas não sei de nenhuma versão - exceto, talvez, o Ovídio de Anguillara - que seja lida com avidez. Qualquer leitor pode descobrir ser a Ilíada de Salvini meticulosamente exata; mas parece a obra de um linguista habilmente pedante, e os conterrâneos do tradutor, os juízes apropriados de seu poder de agradar, a rejeitam com desprezo.

Seus predecessores, os romanos, deixaram algumas traduções em sua esteira, e tal atividade deve ter tido alguma estima pois ocupou Cícero e Júlio César; mas a menos que suponhamos que as peças de Terêncio eram versões de Menandro - o que talvez seja verdadeiro -, nada do que foi traduzido parece jamais ter alcançado uma elevada reputação. Os franceses, no zênite de sua erudição, foram, de maneira louvável, aplicados no enriquecimento de sua língua com a sabedoria dos antigos; mas se limitaram, por uma necessidade qualquer, a transformar as poesias grega e romana em prosa. Quem quer que pudesse ler um autor, poderia traduzi-lo. De tais rivais pouco se pode temer.

O maior auxílio de Pope nessa árdua tarefa veio das versões de Dryden [da mesma Ilíada]. Virgílio tomara muito de suas figuras retóricas de Homero, e 
part of the debt was now paid by his translator. Pope searched the pages of Dryden for happy combinations of heroic diction, but it will not be denied that he added much to what he found. He cultivated our language with so much diligence and art that he has left in his Homer a treasure of poetical elegances to posterity. His version may be said to have tuned the English tongue, for since its appearance no writer, however deficient in other powers, has wanted melody. Such a series of lines so elaborately corrected and so sweetly modulated took possession of the public ear; the vulgar was enamoured of the poem, and the learned wondered at the translation.

But in the most general applause discordant voices will always be heard. It has been objected by some, who wish to be numbered among the sons of learning, that Pope's version of Homer is not Homerical; that it exhibits no resemblance of the original and characteristic manner of the Father of Poetry, as it wants his awful simplicity, his artless grandeur, his unaffected majesty. This cannot be totally denied, but it must be remembered that "necessitas quod cogit defendit", that may be lawfully done which cannot be forborne. Time and place will always enforce regard. In estimating this translation consideration must be had of the nature of our language, the form of our metre, and, above all, of the change which two thousand years have made in the modes of life and the habits of thought. Virgil wrote in a language of the same general fabric with that of Homer, in verses of the same measure, and in an age nearer to Homer's time by eighteen hundred years; yet he found even then the state of the world so much altered, and the demand for elegance so much increased, that mere nature would be parte dessa dívida foi agora paga por seu tradutor. Pope buscou nas páginas de Dryden combinações auspiciosas de dicção heroica; mas não se pode negar que adicionou muito àquilo que encontrou. Ele cultivou nosso idioma com tamanho cuidado e arte que em seu Homero deixou para a posteridade um tesouro de belezas poéticas. Pode-se dizer que sua versão refinou a língua inglesa, pois, desde sua aparição, nenhum escritor, ainda que deficiente em outras habilidades, careceu de melodia. Uma coleção de versos tão elaboradamente desprovida de faltas e tão agradavelmente modulada se apossou do ouvido público; o homem vulgar se enamorou do poema e os eruditos maravilharam-se com a tradução.

Mas em meio aos aplausos gerais, vozes discordantes sempre serão ouvidas. Alguns críticos, desejosos de figurar entre os discípulos da erudição, objetaram que a versão de Homero produzida por Pope não é homérica; que não exibe nenhuma semelhança com o original e com a técnica característica do Pai da Poesia, pois carece de sua simplicidade solene, de seu esplendor natural, de sua majestade simples. Isso não pode ser inteiramente negado, mas é preciso lembrar que "necessitas quod cogit defendit" [a necessidade defende aquilo que impõe], que é lícito fazer aquilo que não se pode refrear. O tempo e o lugar sempre imporão um olhar. Ao avaliar essa tradução, deve-se considerar a natureza de nossa linguagem, a forma de nosso metro, e, sobretudo, a mudança que dois mil anos ocasionaram nos modos de vida e formas de pensamento. Virgílio escreveu numa língua com a mesma estrutura geral do que a de Homero, em versos de mesma medida, e numa época em oitocentos anos mais próxima à do poeta grego; contudo, ele encontrou o estado do mundo tão alterado, e a exigência por elegância tão acrescida, que 
endured no longer; and perhaps, in the multitude of borrowed passages, very few can be shewn which he has not embellished.

There is a time when nations emerging from barbarity, and falling into regular subordination, gain leisure to grow wise, and feel the shame of ignorance and the craving pain of unsatisfied curiosity. To this hunger of the mind plain sense is grateful; that which fills the void removes uneasiness, and to be free from pain for a while is pleasure; but repletion generates fastidiousness, a saturated intellect soon becomes luxurious, and knowledge finds no willing reception till it is recommended by artificial diction. Thus it will be found in the progress of learning that in all nations the first writers are simple, and that every age improves in elegance. One refinement always makes way for another, and what was expedient to Virgil was necessary to Pope.

I suppose many readers of the English Iliad, when they have been touched with some unexpected beauty of the lighter kind, have tried to enjoy it in the original, where, alas! it was not to be found. Homer doubtless owes to his translator many Ovidian graces not exactly suitable to his character; but to have added can be no great crime if nothing be taken away. Elegance is surely to be desired if it be not gained at the expence of dignity. A hero would wish to be loved as well as to be reverenced.

To a thousand cavils one answer is sufficient; the purpose of a writer is to be read, and the criticism which would destroy the power of pleasing must be blown aside. Pope wrote for his own age and his own nation: he knew that it was necessary to colour the images and point the sentiments of his author; he therefore a mera naturalidade não seria mais tolerada; e talvez, na multidão de passagens emprestadas, pode se revelar muito poucas que ele não tenha adornado.

Em algum momento, as nações que emergem da barbárie, e que se acomodam numa ordem estabelecida, conquistam o ócio que lhes permite se tornarem cultas, e sentem a vergonha da ignorância e a dor ardente da curiosidade insatisfeita. A essa fome da alma o senso comum é grato; aquilo que preenche o vazio remove o incômodo, e estar livre da dor por um instante é sentir prazer; mas a plenitude conduz à exigência; um intelecto saturado logo torna-se requintado, e o saber não encontra boa recepção até que seja transmitido por uma dicção elaborada com arte. Assim, verificar-se-á no progresso do saber que, em todas as nações, os primeiros escritores são simples, e que cada época se aperfeiçoa em requinte. Um refinamento sempre abre caminho para outro, e o que era expediente para Virgílio torna-se necessário para Pope.

Acredito que muitos dos leitores da Ilíada inglesa, quando tocados por uma inesperada beleza de fino requinte, buscaram desfrutá-la no original, onde, ah!, não se a podia encontrar. Homero, indubitavelmente, deve a seu tradutor muitos adornos ovidianos não totalmente apropriados ao seu caráter; mas adicionar algo pode não ser um grande crime se nada for retirado. A elegância deve certamente ser desejada se não for obtida às expensas da dignidade. Um herói desejaria ser amado tanto quanto reverenciado.

A milhares de objeções capciosas uma resposta é o bastante: o propósito de um escritor é ser lido e a crítica que queira destruir o poder de agradar deve ser colocada de lado. Pope escreveu para sua própria época e sua própria nação: ele sabia que era necessário dar cor às imagens e realçar a sensibilidade de seu 
made him graceful, but lost him some of his sublimity.

The copious notes with which the version is accompanied and by which it is recommended to many readers, though they were undoubtedly written to swell the volumes, ought not to pass without praise: commentaries which attract the reader by the pleasure of perusal have not often appeared; the notes of others are read to clear difficulties, those of Pope to vary entertainment.

It has, however, been objected with sufficient reason that there is in the commentary too much of unseasonable levity and affected gaiety; that too many appeals are made to the ladies, and the ease which is so carefully preserved is sometimes the ease of a trifler. Every art has its terms and every kind of instruction its proper style; the gravity of common critics may be tedious, but is less despicable than childish merriment.

Of the Odyssey nothing remains to be observed; the same general praise may be given to both translations, and a particular examination of either would require a large volume. The notes were written by Broome, who endeavoured not unsuccessfully to imitate his master. autor; desse modo, fê-lo gracioso, ainda que lhe tenha tirado algo de sua sublimidade.

As copiosas notas que acompanham a versão, motivo pelo qual é recomendada a muitos leitores, embora tenham sido escritas para inchar os volumes, sem dúvida, não devem prescindir de elogios: comentários que seduzem o leitor pelo prazer do exame minucioso não surgem com frequência; as notas de outros são lidas com o intuito de esclarecer dificuldades; as de Pope diversificam a fruição.

Porém, objetou-se com suficiente razão que há nos comentários muitas veleidades inoportunas e ornamentações afetadas; que se faz muito apelo às mulheres; e que a naturalidade cuidadosamente preservada é por vezes a naturalidade de um zombeteiro. Toda arte tem seus termos e todo tipo de instrução, seu próprio estilo; a gravidade dos críticos comuns pode ser tediosa, mas é menos desprezível do que a alegria infantil.

Da Odisséia nada resta a ser observado; o mesmo elogio geral pode ser feito a ambas as traduções, e um exame detido de uma ou de outra requereria um volume maior. As notas foram escritas por Broome, quem se esforçou, não sem sucesso, em imitar seu mestre.

Tradutores:

Gustavo Althoff gualthoff@gmail.com Doutor em Estudos da Tradução, Universidade Federal de Santa Catarina

Mauri Furlan maurizius@gmail.com Prof. Dr., Universidade Federal de Santa Catarina

Fonte: Johnson, Samuel. From 'Life of Pope', in The Lives of the English Poets. Vol. II. London: J.F. Dove, 1826, p. 292-294 